\title{
The De gestis Britonum in Castile
}

\author{
Paloma Gracia
}

The influence of the De gestis Britonum in Castile was profound and extensive. There are two characters in particular that truly transcend and are recreated again and again in different ways: one is Brutus, whose story is incorporated to a greater or lesser extent in different works, among which stands out the General estoria of Alfonso x; the other is Merlin, in his capacity as a prophet, particularly because the collection of prophecies inserted in the $D G B$ is incorporated, almost in its entirety, into the Baladro del sabio Merlín con sus profecias published in 1498 and in the version edited in 1535 . Even if we were to leave aside any short or superficial echo of the $D G B$, of which there are many, the influence of the $D G B$ in Castilian historiography and in Arthurian romance was very important; the connection between Brutus and the Trojan myth expanded the influence of the $D G B$, and Merlin's reputation as a necromancer revived a lagging, though interesting, prophetic genre.

\section{De gestis Britonum}

The moment in which the $D G B$ was introduced to Castile, as well as the route of its diffusion, is in truth unknown. Traditional scholarship, which begins with Entwistle (1922), connects this moment to the marriage alliances of the kings Alfonso VII of León and Castile (1105-57) and Alfonso VIII of Castile (1155-1214), who became fathers-in-law of Louis VII and Louis VIII of France by marrying off their daughters Constance of Castile $(c .1136-60)$ and Blanche of Castile (1188-1252), respectively. Alfonso VII was the son of Raymond of Burgundy and Alfonso viII was the husband of Eleanor of England (or Eleanor Plantagenet), daughter of Eleanor of Aquitaine. ${ }^{1}$ Later scholarship reconsiders

1 This essay is indebted, in some paragraphs, to the one published as P. Gracia, "Arthurian Material in Iberia", in D. Hook (ed.), The Arthur of the Iberians: The Arthurian Legends in the Spanish and Portuguese Worlds (Arthurian Literature in the Middle Ages, 8), Cardiff, 2015, pp. 11-32. The founding scholarship on this topic is the essay by W.J. Entwistle, "Geoffrey of Monmouth and Spanish Literature", Medieval Literature Review 17:4 (1922), 381-91, although many of his essential points have been disputed, particularly by L. Kasten, "The Utilization of the Historia Regum Britanniae by Alfonso X", Hispanic Review 38:5 (1970), 
the role of Eleanor of England's literary patronage in the Castilian courts, limiting her influence to the concession that it may have been particularly easy to acquire a copy of the $D G B$ in the Castilian court under her literary patronage. The Anales navarro-aragoneses (1196) and the Anales toledanos primeros (1219) mention the battle that took place between Arthur and Mordred in Camlan: both give the event the same date of $542 \mathrm{AD}$; the Anales toledanos primeros mention that Mordred is Arthur's nephew. ${ }^{2}$

Eleanor could also have had something to do with the interest that her grandson, King Alfonso X, showed toward Geoffrey's text. The inclusion of the $D G B$ in the General estoria ("The Universal History") could have also been suggested by French historiography, which had already incorporated materials derived from the work of Geoffrey: thus the Histoire ancienne jusqu'à César ("Ancient History According to Caesar"), used by Alfonso x himself, was a structural and ideological model for his General estoria. ${ }^{3}$

Four parts (partes) of the General estoria draw from the $D G B$. The group constitutes what Alfonso $\mathrm{x}$ calls the Estoria de las Bretannas ("The History of the Britons"), which is unevenly distributed among the different parts: it begins at the end of part II, by inserting the story of Brutus into the thread of 1 Kings, and ends in part $\mathrm{v}$, when the compilation narrates the time period of Julius Caesar. The references to biblical passages that Alfonso $\mathrm{x}$ finds in the $D G B$ determine the insertion point of the different materials from Geoffrey's text. The

97-114, and A. Deyermond, "Problems of Language, Audience, and Arthurian Source in a Fifteenth-Century Castilian Sermon", in A. Torres-Alcalá et al. (eds.), Josep María Solà-Solé: homage, homenaje, homenatge: miscelánea de estudios de amigos y discípulos (Biblioteca Universitaria Puvill. v, Estudios misceláneos, 1), Barcelona, 1984, pp. 43-54. Kasten disagreed with the reason given to explain how Alfonso $\mathrm{x}$ acquired a copy of the $D G B$, as well as the way in which he adapted the work. Deyermond's observations have more reach, covering the entire period the $D G B$ was in use and discussing the role of Eleanor of Aquitaine in its introduction, which Entwistle had deemed decisive; Deyermond's consideration that the first text containing material derived from the $D G B$ is the Corónicas navarras led him to restrict the role of Eleanor in the dissemination of Geoffrey's work. In Deyermond's opinion, Eleanor would have limited herself to encouraging, in Castile, an interest that had arisen previously in Navarre that was strengthened by certain historical events concerning Alfonso $\mathrm{x}$.

2 A.P. Hutchinson, "Reading between the Lines: A Vision of the Arthurian World Reflected in Galician-Portuguese Poetry", in B. Wheeler (ed.), Arthurian Studies in Honour of P.J.C. Field, Cambridge, 2004, pp. 117-32; "Anales navarro-aragoneses hasta 1239: edición y estudio", ed. F. Bautista, e-Spania 26 (2017), <http://journals.openedition.org/e-spania/26509> (accessed 30 May 2018).

3 P. Gracia, "Hacia el modelo de la General estoria. París, la translatio imperii et studii y la Histoire ancienne jusqu'à César", Zeitschrift für romanische Philologie 122 (2006), 17-27. For the edition, see Alfonso x, General estoria, ed. P. Sánchez Prieto-Borja, A. Cabrejas, and M. Belén, General estoria. Segunda Parte, 2 vols., Madrid, 2009. 
incorporation is done carefully, avoiding inconsistencies and redundancies and working in harmony with Alfonso's project, both in terms of structural complexity and in terms of ideological purpose. The compilation is especially interested in problems related to dynastic succession, such as the partition of Britain into three regions, one for each of Brutus's children, and the female succession of King Lear. Geoffrey's text enjoyed absolute credibility and the only probable reason that the General estoria does not include more sections of the $D G B$ is that, although Alfonso $\mathrm{x}$ desired that the chronicle should conclude with an account of his own reign, the extant manuscripts abruptly end at the lives of the Virgin Mary's parents, and so it is not possible to know the full extent of the compilation.

The success of the Trojan material, the influence of the General estoria, and the desire of King Pedro I of Castile to emulate his father, King Alfonso XI, were the main motivations for the adaptation of the $D G B$ in 14th-century Castile. Pedro I of Castile, aiming to surpass the version of the Crónica troyana composed during the reign of Alfonso XI, which was fundamentally a prose version of the Roman de Troie, promoted a new version of the Historia troyana, composed between 1365 and 1369. The Historia Troyana of Pedro I includes new material, interspersed throughout the Roman de Troie, that comes from Alfonso's General estoria, although not directly from the extant compilation, but from an independent, lost copy of the Libro de Troya. ${ }^{4}$ The updated Historia Troyana deals especially with what happened after the fall of Troy, generously accepting the events of Aeneas and Brutus derived from an account in the $D G B$, perhaps through a French intermediary version. Thus, based on the $D G B$, the insertions tell the story of Brutus from his birth to the episode about Pandrasus's court, where the story stops, due to the loss of the last folios of the single manuscript that preserves this section (Madrid, Biblioteca Nacional de España, 10146); but it is presumed that the original story also would have covered the conquest of Britain.

Later, the story of Brutus would be included in many historiographical texts of the late Middle Ages, although Geoffrey's Latin original was replaced by the adaptations of the $D G B$ that were already available in Iberian romances and in Wace's Roman de Brut: this is the case for the Crónica de 1404, the Libro de las generaciones, the Sumas de la historia troyana, and the Victorial by Gutierre Díaz de Games. Sometimes, if the passage is short, it is difficult to discern whether the source is an Iberian synthesis of the $D G B$ or of the Roman de Brut.

4 R. Pichel Gotérrez, "Lean por este libro que o acharam mays complidamente ...: del Libro de Troya alfonsí a la Historia troyana de Pedro I", Troianalexandrina: Anuario sobre literatura medieval de materia clásica 16 (2016), 55-180. 


\section{Prophetiae Merlini}

In addition to the historiographical texts and materials derived from the so-called Post-Vulgate Arthurian cycle, Castile enjoyed a wide tradition of prophecies attributed to Merlin, which circulated as a collection and were incorporated into different works. ${ }^{5}$ Baladro del sabio Merlín con sus profecías ("The Cry of Merlin the Wise and his Prophecies") was published in 1498: it is the first printed version of the Arthurian Merlin and the Post-Vulgate Suite $d u$ Merlin, and was published in Burgos. Later, under the global title of $L a$ Demanda del Sancto Grial con los maravillosos fechos de Lançarote y de Galaz su hijo. 1535 ("The Quest for the Holy Grail with the Marvelous Deeds of Lancelot and his son Galahad. 1535"), a printer in Seville published two books: a primero libro de la "Demanda del Sancto Grial", which was a text closely related to the Baladro from Burgos, and a segundo libro de la "Demanda del Sancto Grial", derived from the Queste del Saint Graal of the same cycle. Both editions (1498 and 1535 , respectively) insert the prophetic sections of the $D G B$ in the same place as Geoffrey added them, that is, after Vortigern asks about the meaning of the dragons. It is difficult to determine the moment when these prophecies were incorporated into the Peninsular versions of the Merlin of the Post-Vulgate, although the Vindel manuscript of the Crónica de 1404 (New York, Hispanic Society of America, B2278) suggests the possibility that the prophecies were already part of a Libro del Valadro de Merlim (a certain "Book of the Cry of Merlin") by the first third of the 15th century. In addition, although the prophetic collection is a direct translation of the Latin original, it is possible that there was a French translation of the prophecies that perhaps - although it did not serve as an original translation - inspired the addition of the prophecies.

To the prophecies derived from the $D G B$, essentially the same ones offered by the Baladro from Burgos, La Demanda del Sancto Grial of 1535 adds two collections of prophecies attributed to Merlin but of Peninsular origin: one short and the other extensive, located between the first and second books. This is because once the narration of the death of Merlin is finished, the publication offers one last chapter titled De algunas profecías que el sabio Merlín dixo antes de su muerte ("On Some Prophecies Which Merlin the Wise Told Before his Death") which contains a long, extensive collection of prophecies concerning events tied to Castilian politics, the most modern of which dates to 1467 . This

5 P. Cartelet, "Capítulo VIII. Las profecías interpoladas del Baladro del sabio Merlín: la ambición de una enciclopedia merliniana”, in 'Fágote de tanto sabidor'. La construcción del motivo profético en la literatura medieval hispánica (siglos XIII-XV), Les Livres d'e-Spania "Études", 2016, <http://journals.openedition.org/e-spanialivres/1044> (accessed 24 June 2019). 
collection of prophecies attributed to Merlin constitutes an amalgam of materials whose origin, dating, and purpose are diverse; hence the difficulty they offer, both in terms of understanding the facts they allude to and in terms of their reading and editing. The most extensive collection preserved is that which is inserted under the heading Aquí comiençan las profecías del sabio Merlín, profeta digníssimo, "Here begin the prophecies of Merlin the Wise, a most worthy prophet." Several key parts stand out in this collection: the so-called Visión de Alfonso en la ciudad de Sevilla, "The vision of Alfonso in the city of Seville", for which there is also a Catalan version, in which an angel reveals to the king that the curse he has uttered will cause the loss of his lineage up to four generations; the Profecías que revela Merlin a Maestre Antonio, "Prophecies that Merlin revealed to Master Antonio", which begin with the loss of Spain by King Rodrigo; and the Profecías de Merlín cerca de la ciudad de Londres, "Merlin's prophecies about the city of London", which allude to Alfonso X, Alfonso XI, Pedro I, and Enrique II, and extend to the year 1377. This last group in the collection was translated into Catalan, and is preserved in Barcelona, Biblioteca de Catalunya, 271, copied at the beginning of the $15^{\text {th }}$ century. This manuscript offers a version of the prophecies that is better than the ones in the Sevillian Demanda del Sancto Grial: they are more correct and contain elements that the Castilian edition printed in 1535 has lost. The prophecies attributed to Merlin and related to this tradition or collection served as a model for those contained in the Poema de Alfonso XI, the Crónica del rey don Pedro, and the Cancionero de Baena ("The Songbook of Baena").

Translated from Spanish by Nahir I. Otaño Gracia 